\title{
Upper Paraná River floodplain: synthesizing knowledge over time
}

\author{
Planície de inundação do Alto Rio Paraná: sintetizando o conhecimento ao longo do tempo
}

\author{
Nicolli Cristina Osório ${ }^{1 *}$ (D) and Liliana Rodrigues ${ }^{1,2}$
}

${ }^{1}$ Programa de Pós-graduacão em Ecologia de Ambientes Aquáticos Continentais - PEA, Universidade Estadual de Maringá - UEM, Avenida Colombo, 5790 - Bloco G-90, sala 08, CEP 87020-900, Maringá, PR, Brasil

${ }^{2}$ Departamento de Biologia - DBI, Núcleo de Pesquisa em Limnologia, Ictiologia e Aquicultura Nupélia, Universidade Estadual de Maringá - UEM, Avenida Colombo, 5790 - Bloco G-90, sala 08, CEP 87020-900, Maringá, PR, Brasil

*e-mail: nicolli_cristina@hotmail.com

Cite as: Osório, N. C. and Rodrigues, L. Upper Paraná River floodplain: synthesizing knowledge over time. Acta Limnologica Brasiliensia, 2021, vol. 33, e103.

Abstract: Aim: Considering the great environmental and social impact that floodplains have, several studies have been performed in the upper Paraná River floodplain. In this study, we applied a scientometric analysis to understand the evolution of scientific knowledge generated in the Upper Paraná River floodplain, based on studies published in this area. Methods: We searched the literature published from 1995 to 2018 using the indexed database - Thomson ISI Web of Science. The following information was obtained for each scientific article: a) year of publication; b) place of research; c) research institution; d) study approach; e) environments; f) subject matter; g) theoretical approach; h) taxonomic groups. Results: We found 435 published articles from different study areas (such as: exact and earth sciences, environmental sciences, social and human sciences, health sciences) that used this floodplain as a study area. The linear regression model showed an increase in the number of articles throughout the years. Studies with ecological themes were most prominent, ensuring research with various theoretical approaches and different biological communities used as proxies. Conclusions: With this study, we conclude that long-term research was fundamental in generating data to address ecological issues and describe the dynamics of this plain. Studies such as these must have more political and financial support to develop basic scientific studies that can subsidize data for conservation programs and government policies, in order to maintain ecosystem services such as fishing and the availability of quality water.

Keywords: scientometric analysis; temporal trends; long term research; scientific development.

Resumo: Objetivo: Considerando o grande impacto ambiental e social que planícies de inundação possuem, vários estudos foram realizados na Planície de Inundação do Alto rio Paraná. Neste estudo, aplicamos uma análise cienciométrica para entender a evolução do conhecimento científico gerado na planície de inundação do Alto Paraná, com base em estudos publicados nesta área. Métodos: Pesquisamos a literatura publicada de 1995 a 2018 usando o banco de dados indexado - Thomson ISI Web of Science. As seguintes informaçóes foram obtidas para cada artigo científico pesquisado: a) ano de publicação; b) local da pesquisa; c) instituiçâo de pesquisa; d) abordagem de estudo; e) ambientes; f) assunto; g) abordagem teórica; h) grupos taxonômicos. Resultados: Encontramos 435 artigos publicados de diferentes áreas de estudo (como: ciências exatas e da terra, ciências ambientais, ciências sociais e humanas, ciências da saúde) que usaram essa planície de inundação como área de estudo. O modelo de regressáo linear mostrou um aumento no número de artigos ao longo dos anos. Os estudos com temas ecológicos foram os mais destacados, garantindo pesquisas com diversas 
abordagens teóricas e diferentes comunidades biológicas utilizadas como proxies. Conclusáo: Com este estudo, concluímos que a pesquisa de longo prazo foi fundamental na geração de dados para abordar questóes ecológicas e descrever a dinâmica dessa planície. Estudos como esses devem ter mais apoio político e financeiro para desenvolver pesquisas científicas básicas que possam subsidiar dados para programas de conservação e políticas governamentais, a fim de manter os serviços ecossistêmicos como a pesca e a disponibilidade de água de qualidade.

Keywords: análise cienciométrica; tendências temporais; pesquisa de longo prazo; desenvolvimento científico.

\section{Introduction}

South America holds the largest floodplain area, covering approximately $20 \%$ of the entire continent (Wittmann et al., 2018). Among Brazilian floodplains, the upper Paraná River floodplain is inserted within the Paraná River Basin, which is the second largest Brazilian basin after the Amazon River Basin (Stevaux et al., 1997). This floodplain is the last non-dammed stretch of the Paraná River (Agostinho et al., 1997; Gois et al., 2015) with $230 \mathrm{~km}$ length and $20 \mathrm{~km}$ width (Souza-Filho \& Stevaux, 1997). This area covers the downstream stretch of the Porto Primavera reservoir, situated between the states of Mato Grosso do Sul and São Paulo, and upstream stretch of the Itaipu reservoir, between the states of Mato Grosso do Sul and Paraná (Souza-Filho \& Stevaux, 1997). Furthermore, it is a classic example of a floodplain with high habitat heterogeneity and peculiar limnological characteristics, guaranteeing high regional biotic diversity (Agostinho et al., 1997; Agostinho et al., 2004; Thomaz et al., 2007).

In this stretch, the main channel of the Paraná River is supplied by different tributaries such as the Baía, Ivinhema, Amambaí and Iguatemi rivers on the right bank and the Paranapanema, Ivaí and Piquiri rivers on the left bank (Souza-Filho \& Stevaux, 1997). This floodplain is also composed of a variety of lakes that are important habitats which provide refuge, breeding and development sites for diverse species, and have high diversity and endemism (Agostinho et al., 2005; Thomaz et al., 2007). The region also houses three Conservation Units: Área de Proteção Ambiental das Ilhas e Várzeas do Rio Paraná, Parque Nacional de Ilha Grande, and Parque Estadual das Várzeas do Rio Ivinhema, which are essential for maintaining the terrestrial biodiversity and the plain itself (Agostinho \& Zalewski, 1995; Agostinho et al., 2004).

However, the upper Paraná River floodplain has suffered from strong anthropogenic influences, e.g., reservoir construction (Straškraba et al., 1993; Malmqvist \& Rundle, 2002), whose effects have potentially altered the patterns and processes of abiotic and biotic factors in this type of ecosystem (Ward \& Stanford, 1983). The presence of a reservoir cascade in the Paraná River basin (over 70 dams) has affected the range of hydrometric levels, flood pulse dynamics (Agostinho et al., 2008a, b, 2009), nutrients, the composition of communities and, most importantly, has changed the plain's role in generating ecosystem services such as fishing, water quality and recreation (Agostinho et al., 2000; 2008a; 2009). Additionally, given the great environmental and social impacts that this area has suffered, several multidisciplinary studies have been conducted.

Thus, the importance of this plain in maintaining endemic species and generating ecosystem services is clear, along with its potential for new scientific discoveries. However, it is essential that all knowledge generated from these scientific discoveries be organized to serve as a basis for environmental policies and a guide for ecosystem management. In addition, many articles are published annually, making it difficult for scientists to keep up with the progress within their scientific fields (Garfield, 1992). Therefore, scientometric studies are used to compile such information, guaranteeing the progress of science and technology, as well as providing a global view of research activities (Garfield, 1992; Dalpé, 2002; Strehl \& Santos, 2002). Scientometric techniques can emphasize the trends and contributions of a theory, a scientist or research group, and even institutions or countries about scientific and technological advances throughout the world (Carneiro et al., 2008). Hence, scientometric indicators help point out the immediate results and the effects of the effort aimed at science.

Furthermore, a scientometric study about the upper Paraná River floodplain could reveal the representativeness of this subject in the scientific literature. Thus, we used a scientometric approach to understand the evolution of scientific knowledge generated in the upper Paraná River floodplain, based on studies published about this area, and identified future study perspectives in the region. This raised some questions: (1) Has there been 
a steady growth in the number of studies over time? (2) Which institutions contributed to the development of studies in this region? (3) Has there been a change in the theme of the works overtime? (4) What theoretical approaches have emerged and been further explored? (5) Which organisms have gained greater visibility throughout the years?

\section{Material and Methods}

We performed a literature search in January 2019 using the indexed database - Thomson ISI Web of Science, selecting articles published up until 2018. The Thomson ISI database was used because it encompasses a wide range of publications and because of the quality of the scientific journals. According to Côté et al. (2013), this is the largest database (more than 8700 journals) and is widely used for this type of study, as it includes many scientific journals that cover different areas. The articles were surveyed by searching for specific words in their titles, abstracts, keywords, and texts, excluding the authors' names and references (Figure 1). We searched the following word combinations: 'Upper Paraná River Floodplain' * OR 'Paraná Floodplain and Lake' * OR 'Upper Paraná River' '*' Ivinhema River '* OR' Ivinheima River '* OR' Bay River '*. The asterisk indicates that all terms were included in the query.

The following information was obtained for each scientific article: a) year of publication; b) place of research; c) research institution; d) study approach (experimental, observational and review); e) environments (upper Paraná River floodplain, Upper Paraná River floodplain and others, Paraná system, Ivinhema system,
Bahia system); f) subject matter (e.g., ecology, taxonomy, molecular, methodological, health, economics/ sociology, geology, limnology, others (Paleolimnology, Hydroclimatology)); g) theoretical approach (e.g., community structure, flood pulse, dam effect, genetic approach, spatial and temporal variation, species invasion, beta diversity, functional approach, species characterization, other ecological approaches, general approaches); h) taxonomic groups (e.g., fish, protozoa and invertebrates, algae, macrophytes, riparian vegetation, vertebrates, parasites, various communities, others).

To study the temporal trend of publications from the period of interest, we plotted the number of articles published throughout the years and examined the trend through a linear regression model. We also plotted graphs of the number of articles published according to each theme, approach and organism, to observe this relationship throughout the years. To identify the location with the most publications, the locations of the corresponding author's institution were used. All analyzes were performed in R Software ( $\mathrm{R}$ Development Core Team, 2014). The vegan package (Oksanen et al., 2018) was used to generate a linear regression model and ggplot2 package (Wickham, 2009) to construct the graphs.

\section{Results and Discussion}

\subsection{General aspects}

We found 435 articles that used the upper Paraná River floodplain as a study area. We observed an increase in the number of articles throughout the years (Figure 2). The first article recorded in

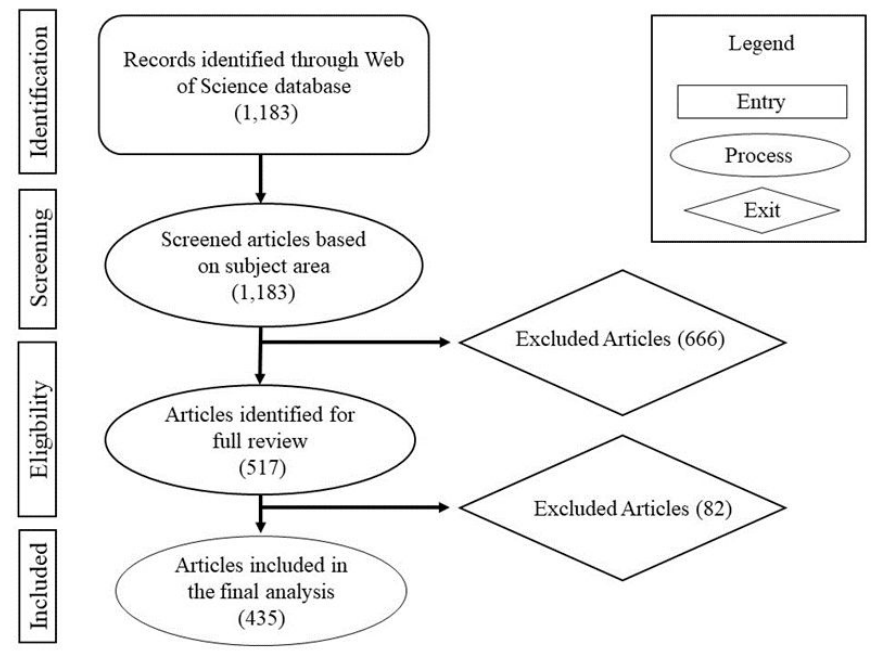

Figure 1. Summary of systematic review steps. PRISMA flow diagram (Moher et al., 2009) summarizing the study inclusion and exclusion phases. 


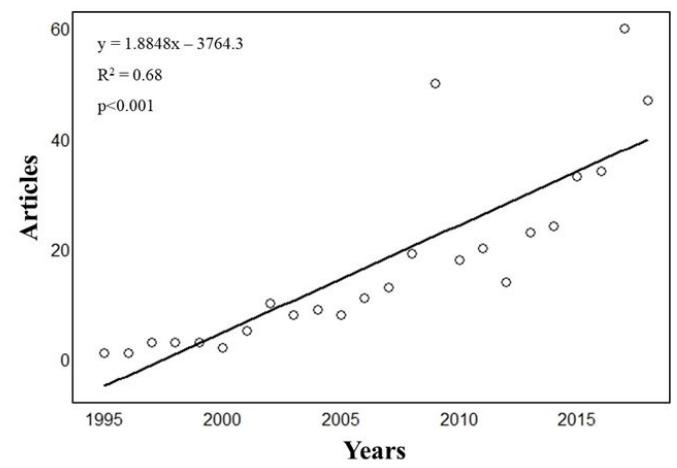

Figure 2. Simple linear regression analysis of the number of articles published from 1995 to 2018 found on the Web of Science (ISI) database.

this study was published in 1995 (Agostinho \& Zalewski, 1995). In the following years there were few publications, with an increase from 2002. In 2009 and 2017, there was an abrupt increase in the number of articles published, since thematic sessions about the Upper Paraná River Flood Plain were opened in 2009 in the Brazilian Journal of Biology and in 2017 in Acta Limnologica Brasiliensia.

The university that most contributed to the research in the region was the Universidade Estadual de Maringá (UEM), with 73\% representation (Figure 3A, Table 1). Since 1983, UEM has been conducting ecological studies at this location, thanks to the consolidation of the Limnology, Ichthyology and Aquaculture Research Center (Nupélia), which houses one of the most important databases on freshwater biology and ecology in Latin America. As shown (Figure 3B), Nupélia is involved with most of the articles found herein (representing about $83 \%$ of the works considering articles written by researchers from Nupélia and those in which this research nucleus participated). In 1991, with the creation of the Postgraduate Program in Ecology of Continental Aquatic Environments, the studies gained more strength, and, with increased collaboration of students and researchers, the articles started being published in indexed journals. In 1999, there was a great rise in research with the implementation of the Long-Term Research Program (PELD-UEM/ $\mathrm{CNPq}$ ), which has been evaluating the long-term effects of anthropogenic actions on environmental processes in the upper Paraná River floodplain for almost 20 years.

In 1994, Acta Limnologia Brasiliensia published a volume (Vol. 5) based on a Workshop on Conservation of Continental Waters Management, in which researchers proposed the creation of a
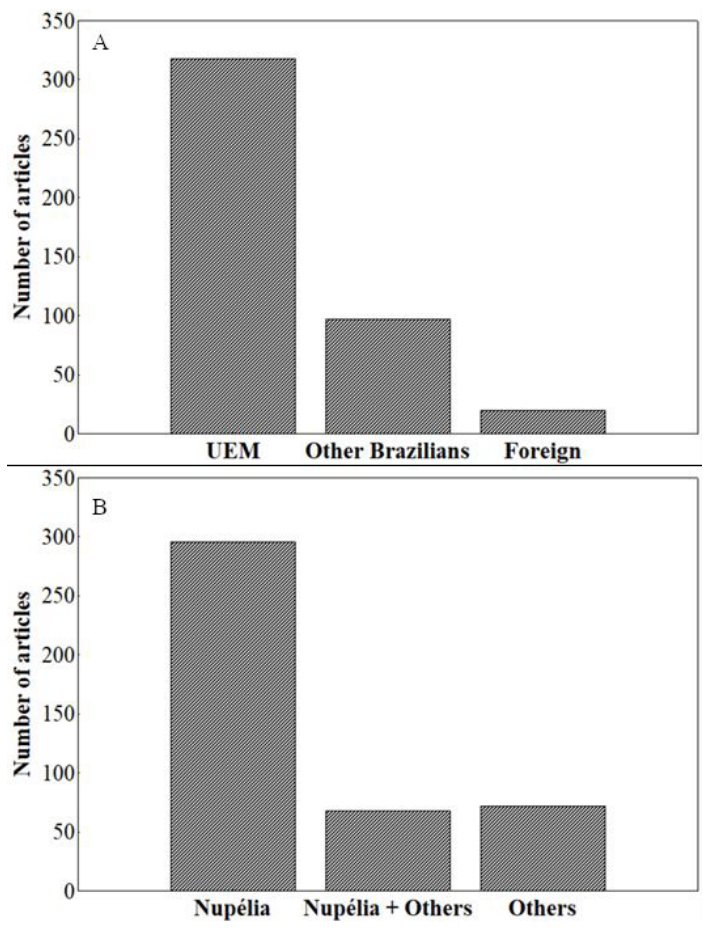

Figure 3. A) Number of articles published by different research institutions from 1995 to 2018, found on the Web of Science (ISI) database. The institutions are UEM (Universidade Estadual de Maringá), other Brazilian (32 research institutions) and foreign (11 foreign institutions), (see details in Table 1). B) Number of articles published by researchers affiliated with the Center for Research in Limnology, Ichthyology and Aquaculture (Nupélia), or research involving partnerships with the Center (Nupélia Partnerships) and research developed by other institutions (Others Institutions) from 1995 to 2018 found in the Web of Science (ISI) database.

Specific Conservation and Management Program for Continental Waters because until then there was no national water policy. In this period, environmental protection projects were carried out, but they focused on terrestrial environments, which did not necessarily include the protection of aquatic systems (Barbosa, 1994). Thus, due to the need to create a Research Program aimed at longterm environmental and ecological monitoring of mainly aquatic environments in Brazil, the president-in-office of the Conselho Nacional de Desenvolvimento Científico e Tecnológico (CNPq), instituted the Integrated Ecology Program in 1997, including PELD.

The PELD represents a pioneering and strategic vision initiative that, since its official implementation in 1999, has fostered a network of reference sites for long-term scientific research, generating qualified knowledge encompassing natural ecosystems and their biodiversity. The PELD network currently 
Table 1. Countries and research institutions of the articles raised in this study.

\begin{tabular}{|c|c|c|}
\hline Countries & Institutions & Number of publications \\
\hline \multicolumn{3}{|l|}{ Brazil } \\
\hline & Faculdade Integrado de Campo Mourão & 1 \\
\hline & Faculdade Integrado de Campo Mourão & 1 \\
\hline & Fundação Dracenense de Educação e Cultura & 1 \\
\hline & Instituto ambiental do Paraná & 2 \\
\hline & Instituto de pesquisas ecológicas & 2 \\
\hline & Instituto Nacional de Limnologia & 1 \\
\hline & Instituto Pró-Pampa & 1 \\
\hline & Universidade Católica de Brasília & 1 \\
\hline & Universidade de Brasília & 1 \\
\hline & Universidade de São Paulo & 1 \\
\hline & Universidade do Estado de Mato Grosso & 1 \\
\hline & Universidade Estadual de Londrina & 8 \\
\hline & Universidade Estadual de Maringá & 317 \\
\hline & Universidade Estadual de Mato Grosso do Sul & 2 \\
\hline & Universidade Estadual de Montes Claros & 1 \\
\hline & Universidade Estadual de Ponta Grossa & 1 \\
\hline & Universidade Estadual de São Paulo & 1 \\
\hline & Universidade Estadual do Centro-Oeste & 1 \\
\hline & Universidade Estadual Do Mato Grosso do Sul & 6 \\
\hline & Universidade Estadual do Oeste do Paraná & 19 \\
\hline & Universidade Estadual Paulista & 13 \\
\hline & Universidade Federal da Grande Dourados & 2 \\
\hline & Universidade Federal da Integração Latino-Americana & 1 \\
\hline & Universidade Federal de Goiás & 5 \\
\hline & Universidade Federal de Rondônia & 1 \\
\hline & Universidade Federal de Santa Catarina & 1 \\
\hline & Universidade Federal de São Carlos & 1 \\
\hline & Universidade Federal Do Mato Grosso do Sul & 1 \\
\hline & Universidade Federal do Paraná & 14 \\
\hline & Universidade Federal do Rio de Janeiro & 2 \\
\hline & Universidade Federal do Rio Grande do Norte & 2 \\
\hline & Universidade Federal do Rio Grande do Sul & 1 \\
\hline & Universidade Federal Fluminense & 1 \\
\hline & Universidade Paranaense & 2 \\
\hline \multicolumn{3}{|l|}{ Argentina } \\
\hline & Cuidad Universitaria Paraje "EI Pozo" & 1 \\
\hline & Universidad Nacional de Mar del Plata & 1 \\
\hline \multicolumn{3}{|l|}{ Belgium } \\
\hline & Royal Belgian Institute of Natural Sciences & 1 \\
\hline \multicolumn{3}{|l|}{ USA } \\
\hline & University of North Texas & 1 \\
\hline & Mississippi Cooperative Fish and Wildlife Research Unit & 1 \\
\hline & Mississippi State University & 5 \\
\hline & Texas A\&M University & 2 \\
\hline & University of Illinois at Springfield & 2 \\
\hline \multicolumn{3}{|l|}{ Scotland } \\
\hline & University of Glasgow & 3 \\
\hline \multicolumn{3}{|l|}{ Finland } \\
\hline & University of Oulu & 1 \\
\hline \multicolumn{3}{|l|}{ Poland } \\
\hline & University of Lod'z & 1 \\
\hline
\end{tabular}


includes 34 research sites distributed across diverse ecosystems (see PELD/CNPq Sites). In addition, PELD is a member of the International Long-Term Ecological Research (ILTER), which brings together 40 member countries and their national long-term ecology research networks, which explains the records of foreign institutions publishing in this field.

Most of the publications analyzed include the different types of environments that correspond to the upper Paraná River floodplain, such as rivers and lakes (Figure 4). According to Souza-Filho (2009), the floodplain is divided by several active river channels, i.e., some tributaries (Baía, Ivinhema, Amambaí and Iguatemi rivers on the right bank and Paranapanema, Ivaí and Piquiri rivers on the left bank) and by intermittent channels where water flows during floods. In addition, there is a considerable set of floodplain lakes, streams, and floodplain areas (flood basin), intermediate areas (crevice deposits) and higher areas (natural dikes). It is important that studies encompass a larger number of environments, as it ensures a better survey of local fauna and flora, a better understanding of the limnological characteristics of this area and is essential for ecological studies that need a large sample size to test theories.

However, studies of only one environment within this ecosystem also show continuous records throughout the years, mainly related to the Paraná River, which comprises the main channel of this plain, and the two largest underlying rivers Baía and Ivinhema, which are linked by several channels that facilitate material exchange and allow flooding to influence both to varying degrees (Arenas-Ibarra, 2008).

Both the Baía and Ivinhema Rivers are less subjected to the effects of the reservoirs than the Paraná River (Agostinho et al. 2004) and features protect riparian cover. Ivinhema subystem is protected by the Parque Estadual das Várzeas do Rio Ivinhema (Arenas-Ibarra et al., 2012). This subsystem is essential for preserving local biodiversity due to its environmental heterogeneity, and presents high input of allochthonous material, as well as production and availability of organic detritus (Azevedo et al., 2008). The Baia river has slightly acidic waters due to the accumulation of humic substances of allochthone origin. (Roberto et al., 2009). Thus, these characteristics suggest that it is an important resource for the entire food web, which could contribute to the dynamics and maintenance of nutrient levels in the upper Paraná River floodplain. Some studies emphasize the importance of these two rivers for spawning and early development of juveniles, especially for migratory species, as well as obtaining food and shelter (Baumgartner et al., 1997; Nakatani et al., 1997; Suzuki et al., 2009).

In addition, from 2011 there has been a significant increase in articles associating floodplain environments and aquatic systems of other regions (Figure 4). This reinforces an increase in the exchange of information and knowledge between

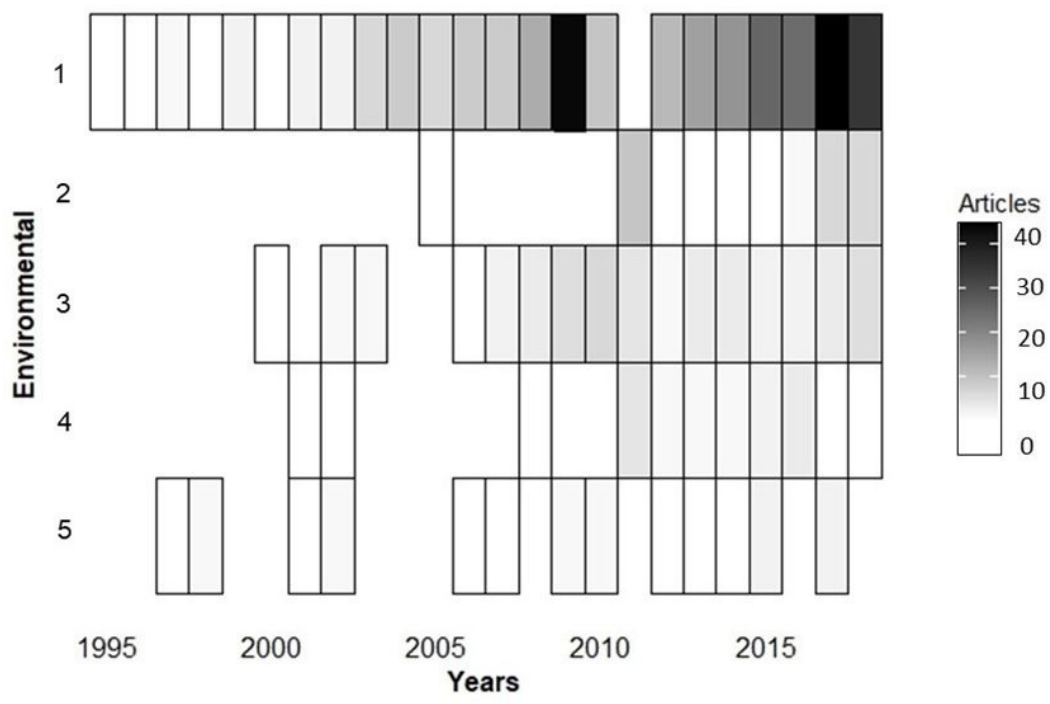

Figure 4. Number of articles from different environments within the study area published from 1995 to 2018 found on the Web of Science (ISI) database. 1. Upper Paraná River floodplain, 2. Upper Paraná River floodplain and others, 3. Paraná System, 4. Ivinhema System, 5. Baía System. 
research groups from different regions, as well as the importance of relating different Brazilian aquatic ecosystems and understanding ecological patterns that can facilitate management and conservation actions in these areas.

\subsection{Study Theme}

Regarding the themes of studies found herein, ecology was the most representative, with $78 \%$ frequency (Figure 5). A 2013 study (Carmel et al., 2013) revealing trends in ecological research found that, while the number of ecological researches has declined over the past 3 decades, these studies still account for over $60 \%$ of biological studies worldwide. In the floodplain where we conducted this study, Nupelia has been conducting ecological research on several communities for over 30 years. Thus, even with the emergence of other study themes, ecological research will remain prominent in this region. In addition, ecology is the best way to identify patterns from population structure to ecosystem services, making it indispensable for management and conservation projects. Monitoring ecological change is critical to making decisions about the future of humanity, as we know that human welfare directly benefits from many ecosystem services (e.g. fishing, recreation/ tourism, water use) promoted by nature. Thus, in light of the changing environmental conditions, ecological monitoring provides decision makers with reliable information to maintain a sustainable economy and a healthy environment.

One approach to ecological monitoring is through long-term studies, which are important for understanding the time dynamics of assemblies and have implications for management and monitoring programs, especially in environments that suffer from dams effects (Schneck et al., 2011). This is because a single sample of the study site may not be sufficient to determine major processes governing community structure (Carneiro et al., 2008). Models formulated by long-term studies help to determine the irregular fluctuations and recurring events that are necessary to develop the future monitoring scenario (Bovo-Scomparin \& Train, 2008). Not all the articles recorded in this paper are part of long-term research data, but most include Nupelia, which conducts most of its research with the help of PELD-UEM / CNPq.

Taxonomic studies have always been present in research in the region, with a frequency of $(6 \%)$ (Figure 5). Since taxonomy is the oldest area of the natural sciences, for many years it was the most representative in biodiversity studies and natural history courses (Bicudo, 2004). In addition, taxonomy helps discover species present in environments, which is fundamental for a posteriori ecological studies. This may be why we observed the continuous approach of taxonomic studies in this plain. All taxonomic works found herein were developed by Nupelia, since all researchers in this

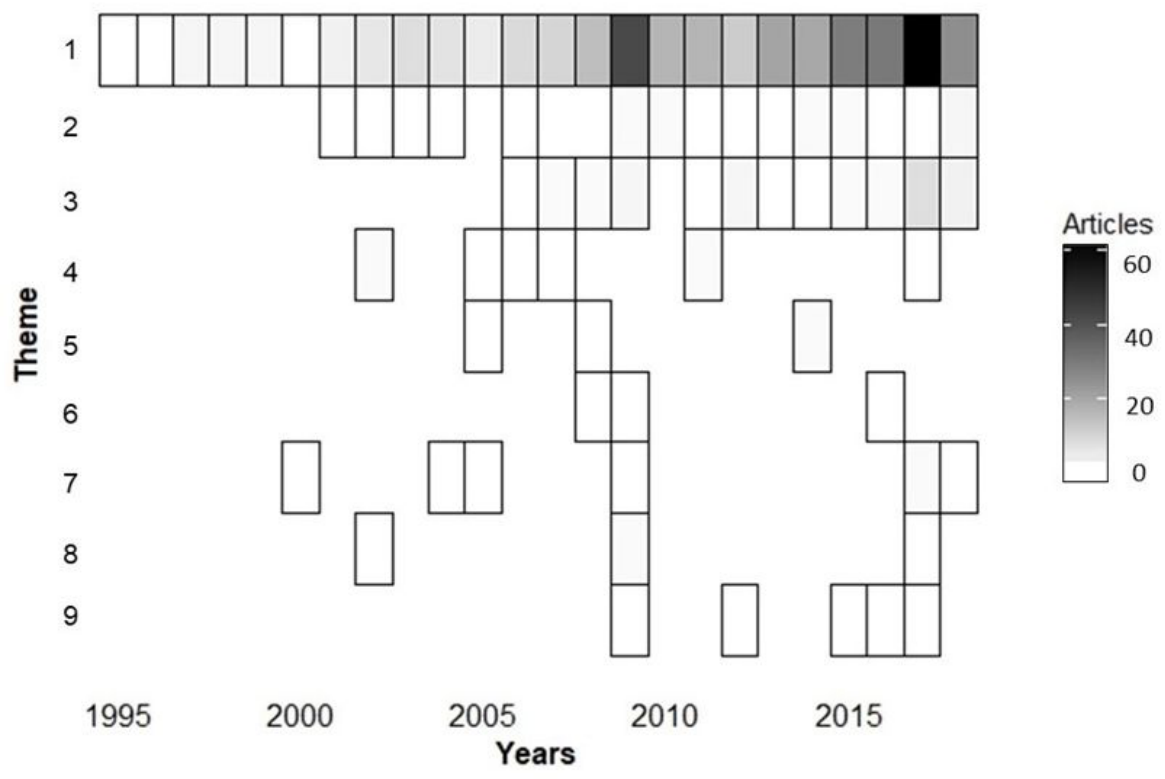

Figure 5. Number of articles with different study themes published between 1995 and 2018 found on the Web of Science (ISI) database. 1. Ecology, 2. Taxonomy, 3. Molecular, 4. Methodological, 5 Health, 6. Economics / Sociology, 7. Geology, 8. Limnology, 9. Others (Paleolimnology, Hydroclimatology). 
group are trained in both ecology and taxonomy, reflecting the works developed in the region.

Taxonomy can help in the discovery and survey of species. The frequency of studies over time in the floodplain (Figure 5) has probably benefited groups of aquatic organisms that previously had been poorly studied such as fish parasites and ostracods, e.g., studies developed by Higuti \& Martens (2012, 2014), Bellay et al. (2009) and Capparros \& Takemoto (2017). This shows that the taxonomically most studied communities were parasites, ostracods, fish and algae.

However, with the emergence of other areas such as molecular biology, taxonomy has been put on the back burner and consequently, the number of researchers devoted to this area has declined. Articles with a molecular theme ( $7 \%$ of representativeness in this study) started being explored in 2006, and since then, these works have added to the scientific development of this region (Figure 5). This is especially true for the most recent years (2017 and 2018), demonstrating the prominence that molecular approaches have been gaining in world science. Recent advances in molecular genetics have generated effective tools for phylogenetic and population studies, enhancing researchers' ability to characterize the biodiversity of diverse ecosystems, as well as to evaluate genetic variability among and within populations. In addition, it helps clarify the evolutionary, taxonomic and demographic relationships for a wide diversity of species. Such information is extremely important when it comes to identifying regions with high diversity for conservation, such as this plain.

It is evident that other themes are gradually being explored in this study region (Figure 5). Such themes include health, sociology and economics, which show concern for the riverside populations and all who somehow benefit from both economic and tourist activities, looking to ensure a quality of life for those who enjoy this ecosystem. Moreover, despite the few works about limnology and geology, these themes have always been developed in this environment because they are essential themes for broad knowledge of the environment. In most ecology studies developed in this area, limnology is included in some way, either as complementary data or in support of the results and discussions presented. Finally, within the group "others", the most dominant theme is related to Paleolimnology, with more recently developed studies (e.g., Ruwer \& Rodrigues, 2017; Ruwer et al., 2018) (Figure 5). This theme has been very prominent because it shows the impacts that the environment has suffered in the past and provides a history of the place, as well as can serve as a tool to access information about climate change.

\subsection{Theoretical approaches}

The first theoretical approaches found in studies developed in the upper Paraná River floodplain were about community structures, spatial and/or temporal variation and species characterization (e.g. Agostinho et al., 1997, 2007; Bonecker \& LansacTôha, 1996; Dei Tos et al., 1997; Higuti et al., 2009, Takeda , 1999; Train \& Rodrigues, 1997; Velho et al., 1999) (Figure 6). This shows that pioneering studies were more descriptive, and more exploratory studies emerged over time. Themes such as beta diversity (e.g. Campos et al., 2018; Dias et al., 2016; Lansac-Toha et al., 2016; Petsch et al., 2017), functional approach (e.g. Almeida et al., 2017; Dunck et al., 2016) and species invasion (e.g. Ernandes-Silva et al., 2016; Garcia et al., 2018; Rodrigues et al., 2018; Souza et al., 2010) only became prominent after 2010. Studies with a genetic approach started being explored in 2002 with Peres et al. (2002), but only gained strength from 2016 (e.g. Ferreira et al., 2017) (Figure 6).

As knowledge advances, a change in trends for theoretical approaches is expected over time. For example, it is logical that early studies in unfamiliar environments would focus on characterizing such locations, as it is difficult to apply theories without first understanding the environmental and biological conditions of the system. Good floristic and faunistic surveys, as well as understanding the limnological and geological conditions of the region, are essential for studies with ecological applications. After characterizing the environment and biology of organisms, information to develop ecological studies becomes more complete. This may explain why studies about community structure and spatial-temporal variations are among the most studied approaches in the plain, as they generate basic and essential information that underpins other theories.

In the past, anthropic impacts were distinct, because there was no exaggeration in agricultural and livestock production and energy. Additionally, little was discussed about climate change. Thus, the studies were more descriptive and the approaches of anthropic impacts on the community were rarer. With the increase of anthropogenic effects on aquatic bodies (mainly dams) and the introduction 


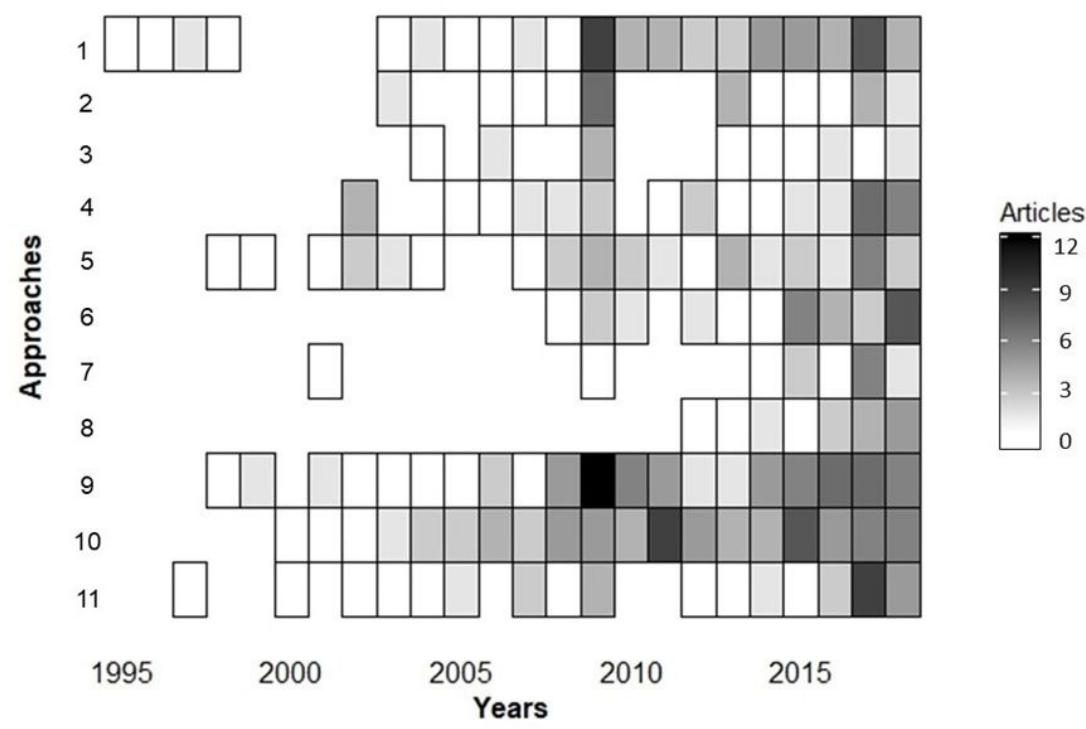

Figure 6. Number of articles from different theoretical approaches from 1995 to 2018 found on the Web of Science (ISI) database. 1. Community structure, 2. Flood pulse, 3. Bus effect, 4. Genetic approach, 5. Spatial and temporal variation, 6. Species invasion, 7. Beta diversity, 8. Functional approach, 9. Species characterization, 10. Other ecological approaches, 11. General (health-related approaches, ecotoxicology).

of new species, approaches have changed. Following the closure of the Porto Primavera dam in 1998, studies about the effects of the dam and flood pulse on aquatic communities have gained prominence and are still being explored in this plain, which was made possible by the PELD. This is because longterm studies compile data that portrays ecological patterns, especially the dynamics of the flood pulse and the various effects that dam constructions have on aquatic ecosystems.

Studies of species invasion gained strength from 2009 onwards, considering that limnological changes caused by the impact of dams were essential for the establishment of invasive species (Figure 6). Features such as the hydroelectric potential of rivers for dam construction (Stevaux et al., 2009), freshwater supply and recreational activities (Agostinho et al., 2007; Vitule et al., 2009; Britton $\&$ Orsi, 2012) are generally the main causes of species invasions in this area. The main vector of invasive species recorded in the upper Paraná River floodplain is damming (Ruaro et al., 2019). One example of invasive species in this plain is the macrophyte Hydrilla verticillata (Lf) Royle, which is one of the most successful aquatic plants in the world (Murphy, 1988; Mullin et al., 2000; Hershner \& Havens, 2008), and has potentially displaced native submerged macrophyte communities (Van et al., 1999; Mony et al., 2007; Wang et al., 2008). Graça \& Pavanelli (2007), recorded about 75 invasive species of fish in the floodplain, among them the tucunaré (Cichla monoculus Bloch \& Schneider), which is a visually oriented and diurnal piscivore. Therefore, its successful invasion after the Porto Primavera dam closed reduced suspended materials and consequently increased water transparency (Espínola et al., 2015).

Observational approaches often do not answer all the questions about changing environments, which explains the evolution of genetic methods, as well as methods using functional and beta diversity approach tools. Both beta diversity and functional diversity have recently attracted a great deal of attention (Anderson et al., 2009), and are important for both theoretical and applied community ecology (Chase, 2010; Socolar et al., 2016). This is because studies about functional diversity aim to estimate the differences between organisms directly through their functional characteristics (Díaz \& Cabido, 2001) and are directly related to the functioning and maintenance of ecological processes because both functional traits and the number of species influence community functioning (Tilman, 2001; Petchey \& Gaston, 2002).

Interest in beta diversity has increased with recognition of its role in identifying and understanding processes that drive diversity patterns at various scales, e.g., regional versus local diversity (Ricklefs, 1987), along with the concept of metacommunity (Leibold et al., 2004). As a result, ecological literature has become full of many different beta diversity measures (e.g. 
Anderson et al., 2009; Baselga, 2010; Legendre, 2014). These measures are potentially useful in developing hypotheses aimed at understanding geographical patterns of diversity in the broadest sense, as beta diversity is driven by several ecological factors (Soininen et al., 2007). The pursuit of these broader ecological standards is essential for applying proper management and conservation techniques in aquatic environments, and tools that measure these standards can only be applied if there is good biological and limnological characterization of these systems.

\subsection{Taxonomic group}

The works developed in the plain involving fish are pioneer studies (Figure 7). It is evident that the number of articles about fish increased considerably from 2008, which explains the increase in the number of taxonomic records from that year. In addition, the number of invasive fish species has been growing exorbitantly in the floodplain, as seen from surveys over time, which compromises regional biodiversity and strongly influences the local economy and environment. Fish assemblages have been used in several studies since the beginning of research in this environment and continue to be the most used organisms (Agostinho et al., 2000; Graça \& Pavanelli, 2007; Ota et al., 2018). Therefore, there are many works involving this community in the plain, with diverse theoretical approaches.
Along with fish research, the first studies related to parasites were basically taxonomic (Pavanelli \& Santos, 1992). In our study, we found that works about this community increased significantly from 2000 (Figure 7). Up until 2004, studies on fish parasites were still focused on species characterization, basically taxonomic works, and rarely related parasites and their respective hosts. However, after 2010 studies involving more current ecological topics came to prominence, such as the relationship between parasite and host and the impact of the plain (Karling et al., 2013), ecological networks (Bellay et al., 2015) and molecular characterization (Gasques et al., 2016).

In addition to fish, other vertebrate groups such as amphibians, birds, and mammals have also been studied in this region, but only started to gain prominence from 2004 (Figure 7), when partnerships with other researchers were provided by the Programa de Pós-graduação em ecologia de ambientes aquáticos continentais (PEA). However, few of these works included ecological aspects of these organisms (Almeida et al., 2017), but rather characterized and recorded these species in the upper Paraná River floodplain (Aguiar et al., 2007).

Protozoa and invertebrates (zooplankton, zoobenthos, ostracods), as well as fish, have been well studied since research began in this plain and are considered great alternatives for ecological and biomonitoring studies. Early studies involving these communities were mainly descriptive, taxonomic,

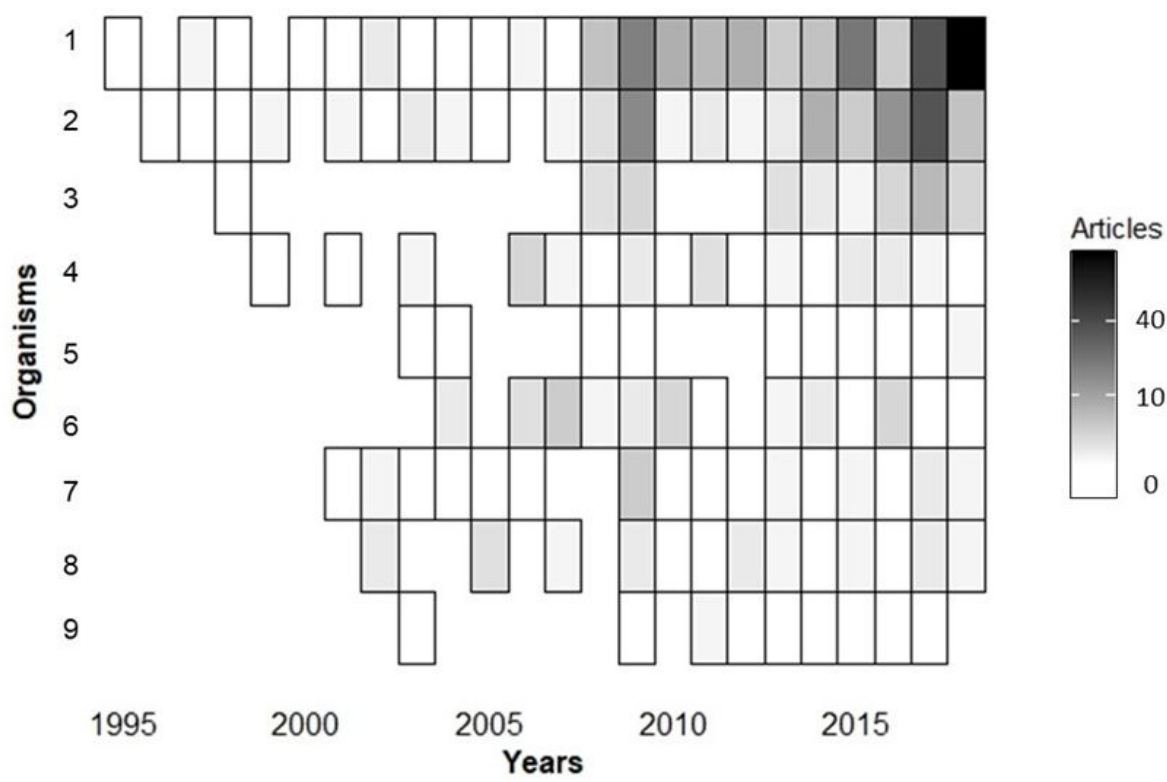

Figure 7. Number of articles about different taxonomic groups published from 1995 to 2018 found on the Web of Science (ISI) database. 1. Fish, 2. Protozoa and Invertebrates, 3. Algae, 4. Macrophytes, 5. Riparian vegetation, 6. Vertebrates, 7. Parasites, 8. Various taxonomic groups, 9. Other (bacteria, fungi, and sponges). 
and community structure-related (Bonecker \& Lansac-Tôha, 1996; Bonecker, 1998; Takeda, 1999; Higuti \& Takeda, 2002; Rosin et al., 2009; Higuti et al., 2009).

Research involving these communities and ecological theories increased after 2009 because such works require more specific taxonomic levels that demand long-term research for good survey. Thus, several theories were more deeply explored, such as habitat complexity (Mormul et al., 2011; Ragonha et al., 2014; Bilia et al., 2015), biological invasions (Mormul et al., 2010; ErnandesSilva et al., 2016), functional approach (Dias et al., 2014), metacommunities (Petsch et al., 2017; Campos et al., 2018; Soares et al., 2015; Dias et al., 2016) and genetic approaches (Schön et al., 2018).

Up until 2000, studies about algal ecology were still very incipient compared to those related to limnology and consumer communities (mainly fish and invertebrates) (Train \& Rodrigues, 1997). However, even in the first decade of 2000, research related to both phytoplankton and periphytic algae gained more visibility and began to be used as a proxy to test various ecological theories (Figure 7). Research about the algae periphytic community in the region began in 1993, with studies by Rodrigues \& Bicudo (2001) about community structure. However, studies involving ecological theories with this community gained more prominence from 2009 (Algarte et al., 2009; Algarte et al., 2016; Dunck et al., 2016; Bichoff et al., 2016). Regarding research on phytoplankton, studies began in 1993 with Train (1998) reporting temporal changes in the structure of this community. Nevertheless, from 2009 is when the largest number of studies were recorded in the region and the most diverse ecological theories were explored (Rodrigues et al., 2009; Bortolini et al., 2017; Pineda et al., 2017; Zanco et al., 2017).

The first macrophyte records for the upper Paraná River floodplain were recorded in conjunction with a survey of terrestrial plants in 1992 (Figure 7). The first specific survey on macrophytes was in 1997 (Thomaz et al., 2004). Studies on this community gained more visibility in 2000 , and since then, macrophytes have been researched in several lines of ecological research. In 2005, with the introduction of Hydrilla verticillata into the environment, studies about species invasions increased (Souza et al., 2010), while research focused on other ecological theories such as flood pulse effects (Padial et al., 2009), habitat complexity (Dibble \& Thomaz, 2009), and metapopulations continued to be carried out (Gubiani et al., 2017). Since then, $H$. verticillata has been monitored in this plain, along with experiments that seek to understand its effects on the structuring of other communities and its invasion potential.

As with macrophytes, the floristic survey of terrestrial plants was carried out between 1992 and 1996. The first studies comprised floristic surveys of the riparian vegetation in this study region. From 2000, studies on structure and spatial distribution of species were initiated (Campos et al., 2000). Besides that, in 2003, Campos \& Souza (2003) studied the potential of natural forest regeneration in the floodplain. In 2005, Truiti et al. (2005) evaluated the antiprotozoal and molluscicide activities of plant species.

Moreover, the Figure 7 shows the number of studies that include several taxonomic groups in the same study has increased. As stated in other topics herein, it is important that studies include a broader range of organisms and environments studied, as the metrics used to test various ecological theories gain greater robustness and ensure effectiveness in the search for ecological standards that require research at the ecosystem level.

\section{Conclusion}

Herein, we conclude that long-term research has helped generate data to address ecological issues and describe the dynamics of this floodplain, which underpins environmental policies and guides ecosystem management. Studies like these need more political and financial support to enable the development of basic scientific studies that can support data for conservation programs. We also highlight the importance of the upper Paraná River floodplain for the maintenance of endemic species and its potential for new discoveries, since wetland ecosystems are recognized as habitat mosaics, encompassing high biological diversity, reinforcing their importance for biodiversity conservation.

In addition, future studies must provide species lists (even in supplementary documents) for any changes in species occurrence or distribution to be identified over time. It is important to highlight that these studies with broader ecological theories could only be developed because of taxonomic revisions, new taxonomic and molecular techniques, new collection methods, and the improvement and hiring of researchers who are essential for increasing this knowledge. Finally, we encourage the maintenance of long-term ecological research in wetlands, as it is essential for assessing biodiversity 
and providing data to guide government policies that can improve the conservation of Brazilian water bodies.

\section{Acknowledgements}

We would like to thank the Coordenação de Aperfeiçoamento de Pessoal de Nível Superior (CAPES) for the PhD scholarship granted to Nicolli Cristina Osório, the Conselho Nacional de Desenvolvimento Científico e Tecnológico (CNPq) for the Liliana Rodrigues Productivity Scholarship, the Long-term Ecological Project (CNPq-PELD-Brasil), and the Núcleo de Pesquisa em Limnologia, Ictiologia e Aquicultura (Nupélia) for technical and logistical support.

\section{References}

AGOSTINHO, A.A. and ZALEWSKI, M. The dependence of fish community structure and dynamics on floodplain and riparian ecotone zone in Parana River, Brazil. Hydrobiologia, 1995, 303(1-3), 141-148. http://dx.doi.org/10.1007/BF00034051.

AGOSTINHO, A.A., JÚLIO JUNIOR, H.F., GOMES, L.C., BINI, L.M. and AGOSTINHO, C.S. Composição, abundância e distribuição espaçotemporal da ictiofauna. In: A.E.A.M. VAZZOLER, A.A. AGOSTINHO and N.S. HAHN, eds. $A$ Planície de Inundação do Alto Rio Paraná. Aspectos fisicos, biológicos e socioeconômicos. Maringá: EDUEM: Nupélia, 1997, pp.179-208.

AGOSTINHO, A.A., GOMES, L.C. and PELICICE, F.M. Ecologia e manejo de recursos pesqueiros em reservatórios do Brasil. Maringá: EDUEM; 2007.

AGOSTINHO, A.A., THOMAZ, S.M., MINTEVERA, C.V. and WINEMILLER, K.O. Biodiversity in the high Paraná river floodplain. In: Gopal, B., Junk, W.J., Davis, J.A., eds. Biodiversity in wetlands: Assessment, function and conservation. Leiden: Backhuys Publishers, 2000, pp. 89-118.

AGOSTINHO, A.A., THOMAZ, S.M. and GOMES, L.C. Threats for biodiversity in the floodplain of the Upper Paraná River: effects of hydrological regulation by dams. Ecohydrology \& Hydrobiology, 2004, 4, 255-268.

AGOSTINHO, A.A., PELICICE, F.M. and GOMES, L.C. Dams and the fish fauna of the Neotropical region: impacts and management related to diversity and fisheries. Brazilian Journal of Biology = Revista Brasileira de Biologia, 2008a, 68(4, Suppl.), 1119-1132. http://dx.doi.org/10.1590/S151969842008000500019. PMid:19197482.

AGOSTINHO, A.A., GOMES, L.C., PELICICE, F.M., SOUZA-FILHO, E.E. and TOMANIK, E.A. Application of the ecohydrological concept for sustainable development of tropical floodplains: the case of the upper Paraná River basin. Ecohydrology \&
Hydrobiology, 2008b, 8(2-4), 205-223. http://dx.doi. org/10.2478/v10104-009-0016-x.

AGOSTINHO, A.A., THOMAZ, S.M. and GOMES, L.C. Conservação da biodiversidade em águas continentais do Brasil. Megadiversidade, 2005, 1(1), 70-78.

AGOSTINHO, A.A., BONECKER, C.C. and GOMES, L.C. Effects of water quantity on connectivity: the case of the upper Paraná River floodplain. Ecohydrology \& Hydrobiology, 2009, 9(1), 99-113. http://dx.doi.org/10.2478/v10104-009-0040-x.

ALGARTE, V.M., SIQUEIRA, N.S., MURAKAMI, E.A. and RODRIGUES, L. Effects of hydrological regime and connectivity on the interannual variation in taxonomic similarity of periphytic algae. Brazilian Journal of Biology = Revista Brasileira de Biologia, 2009, 62(2, Suppl.), 606-616. http://dx.doi.org/10.1590/ S1519-69842009000300015. PMid:19738967.

ALGARTE, V.M., DUNCK, B., LEANDRINI, J.A. and RODRIGUES, L. Periphytic diatom ecological guilds in floodplain: Ten years after dam. Ecological Indicators, 2016, 69, 407-414. http://dx.doi. org/10.1016/j.ecolind.2016.04.049.

AGUIAR, L.M., LUDWIG, G., SVOBODA, W.K., HILST, C.L.S., NAVARRO, I.T. and PASSOS, F.C. Occurrence, local extinction and conservation of Primates in the corridor of the Upper Paraná River, with notes on other mammals. Revista Brasileira de Zoologia, 2007, 24(4), 898-906. http://dx.doi. org/10.1590/S0101-81752007000400006.

ALMEIDA, B.A., GIMENES, M.A.R. and ANJOS, L. Wading bird functional diversity in a floodplain: Influence of habitat type and hydrological cycle. Austral Ecology, 2017, 42(1), 84-93. http://dx.doi. org/10.1111/aec.12403.

ANDERSON, M.J., CRIST, T.O., CHASE, J.M., VELLEND, M., INOUYE, B.D., FREESTONE, A.L., SANDERS, N.J., CORNELL, H.V., COMITA, L.S., DAVIES, K.F., HARRISON, S.P., KRAFT, N.J.B., STEGEN, J.C. and SWENSON, N.G. Navigating the multiple meanings of $b$ diversity: $a$ roadmap for the practicing ecologist. Ecology Letters, 2009, 14(1), 19-28. http://dx.doi.org/10.1111/ j.1461-0248.2010.01552.x. PMid:21070562.

ARENAS-IBARRA, J.A. Conectividade hidrológica no macrossistema fluvial do alto rio Paraná: influência dos reservatórios a montante [Tese de doutorado]. Maringá: Universidade Estadual de Maringá, 2008, $29 \mathrm{p}$.

ARENAS-IBARRA, J.A., TAKEDA, A.M. and FUJITA, D.S. O regime hidrológico do rio Ivinhema (Estado do Mato Grosso do Sul) e sua influência na assembléia zoobentônica. Acta Scientiarum. Biological Sciences, 2012, 34(1), 47-57. http://dx.doi.org/10.4025/ actascibiolsci.v34i1.6481.

AZEVEDO, J.C.R., TEIXEIRA, M.C., SANTOS, A.M., LEANDRINI, J.A. and PAGIORO, T.A. Caracterização espectroscópica da matéria orgânica 
dissolvida da planície de inundação do alto rio Paraná. Oecologia Brasiliensis, 2008, 12, 66-77.

BASELGA, A. Partitioning the turnover and nestedness components of beta diversity. Global Ecology and Biogeography, 2010, 19(1), 134-143. http://dx.doi. org/10.1111/j.1466-8238.2009.00490.x.

BARBOSA, F.A.R. Workshop: Brazilian programme on conservation and management of inland waters. Acta Limnologica Brasiliensia, 1994, 5, 103-111.

BAUMGARTNER, G., NAKATANI, K., CAVICCHIOLI, M. and BAUMGARTNER, M.S.T. Some aspects of the ecology of fish larva in the floodplain of high Paraná River, Brazil. Revista Brasileira de Zoologia, 1997, 14(3), 551-563. http:// dx.doi.org/10.1590/S0101-81751997000300005.

BELLAY, S., TAKEMOTO, R.M., YAMADA, F.H. and PAVANELLI, G.C. Two new species of Sciadicleithrum (Monogenea: Dactylogyridae), gill parasites of Geophagus proximus (Castelnau) (Teleostei: Cichlidae), from the upper Paraná River floodplain, Brazil. Zootaxa, 2009, 208(1), 57-66. http://dx.doi.org/10.11646/zootaxa.2081.1.4.

BELLAY, S., DE OLIVEIRA, E.F., ALMEIDA-NETO, M., MELlO, M.A., TAKEMOTO, R.M. and LUQUE, J.L. Ectoparasites and endoparasites of fish form networks with different structures. Parasitology, 2015, 142(7), 901-909. http://dx.doi.org/10.1017/ S0031182015000128. PMid:25774533.

BICUDO, C.E. Taxonomia. Biota Neotropica, 2004, 4(1), 1-2. http://dx.doi.org/10.1590/S167606032004000100001 .

BICHOFF, A., OSORIO, N.C., DUNCK, B. and RODRIGUES, L. Periphytic algae in a floodpain lake and river under low water conditions. Biota Neotropica, 2016, 16(3), e20160159. http://dx.doi. org/10.1590/1676-0611-BN-2016-0159.

BILIA, C.G., PINHA, G.D., PETSCH, D.K. and TAKEDA, A.M. Influência da heterogeneidade ambiental sobre os atributos da comunidade de Chironomidae em lagoas de inundação neotropicais. Iheringia. Série Zoologia, 2015, 105(1), 20-27. http:// dx.doi.org/10.1590/1678-4766201510512027.

BONECKER, C.C. and LANSAC-TÔHA, F.A. Community structure of rotifers in two environments of the high River Paraná floodplain (MS), Brazil. Hydrobiologia, 1996, 325, 137-150. http://dx.doi. org/10.1007/BF00028274.

BONECKER, C.C. Estudos Populacionais dos rotíferos em diferentes ambientes da planície de inundação do alto rio Paraná-MS [Tese de doutorado]. Maringá: Universidade Estadual de Maringá, 1998, 75 p.

BORTOLINI, J.C., PINEDA, A., RODRIGUES, L.C., JATI, S. and VELHO, L.F.M. Environmental and spatial processes influencing phytoplankton biomass along a reservoirs-river-floodplain lakes gradient: a metacommunity approach. Freshwater Biology, 2017, 62(10), 1756-1767. http://dx.doi.org/10.1111/ fwb. 12986 .
BOVO-SCOMPARIN, V.M. and TRAIN, S. Long-term variability of the phytoplankton community in an isolated floodplain lake of the Ivinhema River State Park, Brazil. Hydrobiologia, 2008, 610(1), 331-344. http://dx.doi.org/10.1007/s10750-008-9448-3.

BRITTON, J.R. and ORSI, M.L. Nonnative fish in aquaculture and sport fishing in Brazil: economic benefits versus risks to fish diversity in the upper River Paraná Basin. Reviews in Fish Biology and Fisheries, 2012, 22(3), 555-565. http://dx.doi.org/10.1007/ s11160-012-9254-x.

CAMPOS, J.B., ROMAGNOLO, M.B. and SOUZA, M.C. Structure, composition and spatial distribution of tree species in a remnant of the semideciduous seasonal alluvial forest of the Upper Paraná River Floodplain. Brazilian Archives of Biology and Technology, 2000, 43(2), 185-194. http://dx.doi. org/10.1590/S1516-89132000000200008.

CAMPOS, J.B. and SOUZA, M.C. Potencial for natural forest regeneration from seed bank in an Upper Paraná River Floodplain, Brazil. Brazilian Archives of Biology and Technology, 2003, 46(4), 625-639. http:// dx.doi.org/10.1590/S1516-89132003000400018.

CAMPOS, R., LANSAC-TÔHA, F.M., CONCEIÇÃO, E.O., MARTENS, K. and HIGUT, J. Factors affecting the metacommunity structure of periphytic ostracods (Crustacea, Ostracoda): a deconstruction approach based on biological traits. Aquatic Sciences, 2018, 80(2), 16. http://dx.doi.org/10.1007/s00027018-0567-2.

CAPPARROS, E.M. and TAKEMOTO, R.M. Gyrodactylidae (Monogenea: Platyhelminthes) gill parasites of Tetragonopterinae (Characiformes: Characidae) from the upper Paraná River floodplain, Brazil. Acta Limnologica Brasiliensia, 2017, 29(0), e105. http://dx.doi.org/10.1590/s2179-975x3817.

CARMEL, Y., KENT, R., BARMASSADA, A., BLANK, L., LIBERZON, J., NEZER, O., SAPIR, G. and FEDERMAN, R. Trends in ecological research during the last three decades - A systematic review. PLoS One, 2013, 8(4), e59813. http://dx.doi.org/10.1371/ journal.pone.0059813. PMid:23637740.

CARNEIRO, F.M., NABOUT, J.C. and BINI, L.M. Trends in the scientific literature on phytoplankton. Limnology, 2008, 9(2), 153-158. http://dx.doi. org/10.1007/s10201-008-0242-8.

CHASE, J.M. Stochastic community assembly causes higher biodiversity in more productive environments. Science, 2010, 328(5984), 1388-1391. http://dx.doi. org/10.1126/science.1187820. PMid:20508088.

CÔTÉ, I.M., CURTIS, P.S., ROTHSTEIN, H.R. and STEWART, G.B. Gathering Data: Searching Literature and Selection Criteria. In: J. KORICHEVA, J. GUREVITCH and K. MENGERSEN, eds. Handbook of meta-analysis in ecology and Evolution. Princeton: Princeton and Oxford Press, 2013, 515 p. 
DALPÉ, R. Bibliometric analysis of biotechnology. Scientometrics, 2002, 55(2), 189-213. http://dx.doi. org/10.1023/A:1019663607103.

DEI TOS, C., AGOSTINHO, A.A. and SUZUKI, H.I. Population structure and reproductive biology of Loricariichthys platymetopon (Siluriformes, Pisces) in the upper river Paraná. Brazilian Archives of Biology and Technology, 1997, 40(4), 793-807.

DIAS, J.D., BONECKER, C.C. and MIRACLE, M.R. The rotifer community and its functional role in lakes of a neotropical floodplain. International Review of Hydrobiology, 2014, 99(1-2), 72-83. http://dx.doi. org/10.1002/iroh.201301706.

DIAS, J.D., SIMÓES, N.S., MEERHOFF, M., LANSAC-TÔHA, F.A., VELHO, L.F.M. and BONECKER, C.C. Hydrological dynamics drives zooplankton metacommunity structure in a Neotropical floodplain. Hydrobiologia, 2016, 781(1), 109-125. http://dx.doi.org/10.1007/s10750-0162827-2.

DIAZ, S. and CABIDO, M. Vive la Difference: Plant Functional Diversity Matters to Ecosystem Processes. Trends in Ecology \& Evolution, 2001, 16(11), 646-655. http://dx.doi.org/10.1016/S0169-5347(01)02283-2.

DIBBLE, E.D. and THOMAZ, S.M. Use of fractal dimension to assess habitat complexity and its influence on dominant invertebrates inhabiting tropical and temperate macrophytes. Journal of Freshwater Ecology, 2009, 24(1), 93-102. http:// dx.doi.org/10.1080/02705060.2009.9664269.

DUNCK, B., SCHNECK, F. and RODRIGUES, L. Patterns in species and functional dissimilarity: insights from periphytic algae in subtropical floodplain lakes. Hydrobiologia, 2016, 763(1), 237247. http://dx.doi.org/10.1007/s10750-015-2379-x.

ERNANDES-SILVA, J., RAGONHA, F.H., RODRIGUES, L.C. and MORMUL, R.P. Freshwater invasibility level depends on the population age structure of the invading mussel species. Biological Invasions, 2016, 18(5), 1421-1430. http://dx.doi. org/10.1007/s10530-016-1091-8.

ESPÍNOLA, L.A., MINTE-VERA, C.V., SANTOS, L.N. and WINEMILLER, K.O. Evaluation of factors associated with dynamics of Cichla ocellaris invasion of the Upper Paraná River floodplain system, Brazil. Marine and Freshwater Research, 2015, 66(1), 33-40. http://dx.doi.org/10.1071/MF13105.

FERREIRA, D.G., SHIBATTA, L.S., SHIBATTA, O.A., SOFIA, S.H., CARLSSON, J., DIAS, J.H.P., MAKRAKIS, S. and MAKRAKIS, C. Genetic structure and diversity of migratory freshwater fish in a fragmented Neotropical river system. Reviews in Fish Biology and Fisheries, 2017, 27(1), 209-231. http:// dx.doi.org/10.1007/s11160-016-9441-2.

GARCIA, D.A.Z., BRITTON, J.R., VIDOTTOMAGNONI, A.P. and ORSI, M.L. Introductions of non-native fishes into a heavily modified river: rates, patterns and management issues in the Paranapanema
River (Upper Paraná ecoregion, Brazil). Biological Invasions, 2018, 20(5), 1229-1241. http://dx.doi. org/10.1007/s10530-017-1623-x.

GARFIELD, E. Contract research services at ISI. Citation analysis for governmental, industrial, and academic clients. Current Contents Connect, 1992, 23, 5-13.

GASQUES, L.S., GRAÇA, R.J., PRIOLI, S.M.A.P., TAKEMOTO, R.M. and PRIOLI, A.J. Molecular characterization of Urocleidoides cuiabai and U. malabaricusi (Monogenea: Dactylogyridae) from the trahira fish Hoplias aff. malabaricus in the Paraná River, Brazil. Journal of Helminthology, 2016, 90(6), 693-697. http://dx.doi.org/10.1017/ S0022149X15000966. PMid:26603609.

GOIS, K.S., PELICICE, F.M., GOMES, L.C. and AGOSTINHO, A.A. Invasion of an Amazonian cichlid in the Upper Paraná River: facilitation by dams and decline of a phylogenetically related species. Hydrobiologia, 2015, 746(1), 401-413. http://dx.doi. org/10.1007/s10750-014-2061-8.

GRAÇA, W.J. and PAVANELLI, C.S. Peixes da planície de inundação do alto Rio Paraná e áreas adjacentes. Maringá: EDUEM, 2007, 308 p.

GUBIANI, E.A., THOMAZ, S.M., BINI, L.M. and PIANA, P.A. Metapopulation models predict the temporal response of two macrophytes to drought in a subtropical water reservoir. Ecological Engineering, 2017, 100, 1-7. http://dx.doi.org/10.1016/j. ecoleng.2016.11.067.

HERSHNER, C. and HAVENS, K.J. Managing invasive aquatic plants in a changing system: strategic consideration of ecosystem services. Conservation Biology, 2008, 22(3), 544-550. http:// dx.doi.org/10.1111/j.1523-1739.2008.00957.x. PMid: 18577083.

HIGUTI, J. and TAKEDA, A.M. Spatial and temporal variation in densities of chironomid larvae (diptera) in two lagoons and two tributaries of the Upper Paraná river Floodplain, Brazil. Brazilian Journal of Biology = Revista Brasileira de Biologia, 2002, 62(4), 807-818. http://dx.doi.org/10.1590/S151969842002000500010 . PMid:12659032.

HIGUTI, J., LANSAC-TÔHA, F.A., VELHO, L.F.M. and MARTENS, K. Biodiversity of non-marine ostracods (Crustacea, Ostracoda) in the alluvial valley of the upper Paraná River, Brazil. Brazilian Journal of Biology = Revista Brasileira de Biologia, 2009, 69(2, Suppl.), 661-668. http://dx.doi.org/10.1590/S151969842009000300020. PMid:19738972.

HIGUTI, J. and MARTENS, K. Five new species of Candoninae (Crustacea, Ostracoda) from the alluvial valley of the Upper Paraná River (Brazil, South America). European Journal of Taxonomy, 2014, 106(106), 1-36. http://dx.doi.org/10.5852/ ejt.2014.106.

HIGUTI, J. and MARTENS, K. On a new cypridopsine genus (Crustacea, Ostracoda, Cyprididae) from the Upper Paraná River Floodplain (Brazil). Zootaxa, 
2012, 3391(1), 23-38. http://dx.doi.org/10.11646/ zootaxa.3391.1.2.

KARLING, L.C., LACERDA, A.F., ALVARENGA, F.M.S., TAKEMOTO, R.M. and PAVANELLI, G.C. Endoparasites of Rhaphiodon vulpinus (Characiformes: Cynodontidae) and their relation to the standard length and sex of their hosts. Bioscience Journal, 2013, 29(5), 1311-1316.

LANSAC-TOHA, F.M., MEIRA, B.R., SEGOVIA, B.T., LANSAC-TOHA, F.A. and VELHO, L.F.M. Hydrological connectivity determining metacommunity structure of planktonic heterotrophic flagellates. Hydrobiologia, 2016, 781(1), 81-94. http://dx.doi.org/10.1007/s10750-016-2824-5.

LEGENDRE, P. Interpreting the replacement and richness difference components of beta diversity. Global Ecology and Biogeography, 2014, 23(11), 1324-1334. http://dx.doi.org/10.1111/geb.12207.

LEIBOLD, M.A., HOLYOAK, M., MOUQUET, N., AMARASEKARE, P., CHASE, J.M., HOOPES, M.F., HOLT, R.D., SHURIN, J.B., LAW, R., TILMAN, D., LOREAU, M. and GONZALEZ, A. The metacommunity concept: a framework for multi-scale community ecology. Ecology Letters, 2004, 7(7), 601-613. http://dx.doi.org/10.1111/j.14610248.2004.00608.x.

MALMQVIST, B. and RUNDLE, S. Threats to the running water ecosystems of the world. Environmental Conservation, 2002, 29(2), 134-153. http://dx.doi. org/10.1017/S0376892902000097.

MOHER, D., LIBERATI, A., TETZLAFF, J. and ALTMAN, D.G., and the PRISMA Group Preferred reporting items for systematic reviews and metaanalyses: The PRISMA statement. PLoS Medicine, 2009, 6(7), e1000097. http://dx.doi.org/10.1371/ journal.pmed.1000097. PMid:19621072.

MONY, C., KOSCHNICK, T.J., HALLER, W.T. and MULLER, S. Competition between two invasive (Hydrocharitaceae Hydrilla verticillata (L.f.) (Royle) and Egeria densa (Planch)) as influenced by sediment fertility and season. Aquatic Botany, 2007, 86(3), 236-242. http://dx.doi.org/10.1016/j. aquabot.2006.11.007.

MORMUL, R.P., THOMAZ, S.M., TAKEDA, A.M. and BEHREND, R.D. Structural complexity and distance from source habitat determine invertebrate abundance and diversity. Biotropica, 2011, 43(6), 738-745. http://dx.doi.org/10.1111/j.17447429.2011.00762.x.

MORMUL, R.P., FERREIRA, F.A., MICHELAN, T.S., CARVALHO, P., SILVEIRA, M.J. and THOMAZ, S.M. Aquatic macrophytes in the large, sub-tropical Itaipu Reservoir, Brazil. Revista de Biología Tropical, 2010, 58(4), 1437-1452. PMid:21246998.

MULLIN, B.H., ANDERSON, L.W.J., DITOMASO, J.M., EPLEE, R.E. and GETSINGER, K.D. Invasive plant species. CAST, 2000, 13, 1-18.
MURPHY, K.J. Aquatic weed problems and their management: a review. I. The worldwide scale of the aquatic weed problem. Crop Protection (Guildford, Surrey), 1988, 7(4), 232-248. http:// dx.doi.org/10.1016/0261-2194(88)90044-0.

NAKATANI, K., BAUMGARTNER, G. and CAVICCHIOLI, M. Ecologia de ovos e larvas de peixes. In: A.E.A.M. VAZZOLER, A.A. AGOSTINHO and N. S. HAHN, eds. A planicie de inundação do alto rio Paraná: aspectos físicos, biológicos e socioeconômicos. Maringá: EDUEM, 1997, pp. 281-306.

OKSANEN, J., BLANCHET, F.G., FRIENDLY, M., KINDT, R., LEGENDRE, P., MCGLINN, D., MINCHIN, P.R., O'HARA, R.B., SIMPSON, G.L., SOLYMOS, P., STEVENS, M.H.H., EDUARD, S.E. and WAGNER, H. Vegan: Community Ecology Package. R package version 2.5-2, 2018.

OTA, R.R., DEPRÁ, G.D.C., GRAÇA, W.J.D. and PAVANELLI, C.S. Peixes da planície de inundaçấo do alto rio Paraná e áreas adjacentes: revised, annotated and updated. Neotropical Ichthyology, 2018, 16(2), 1-111. http://dx.doi.org/10.1590/1982-022420170094.

PADIAL, A.A., CARVALHO, P., THOMAZ, S.M., BOSCHILIA, S.M., RODRIGUES, R.B. and KOBAYASHI, J.T. The role of an extreme flood disturbance on macrophyte assemblages in a Neotropical floodplain. Aquatic Sciences, 2009, 71(4), 389-398. http://dx.doi.org/10.1007/s00027009-0109-z.

PAVANELLI, G.C. and SANTOS, M.H.M. Goezeella agostinhoi sp. n. e Monticellia loyolai sp. n., cestóides proteocefalídeos parasitas de peixes pimelodídeos do Rio Paraná, Paraná, Brasil. Revista Brasileira de Parasitologia Veterinária, 1992, 1(1), 45-50.

PERES, M.D., RENESTO, E., LAPENTA, A.S. and ZAWADZKI, C.H. Genetic variability in Hoplias malabaricus (Osteichthyes: Erythrinidae) in fluvial and lacustrine environments in the upper Paraná river floodplain (Paraná state, Brazil). Biochemical Genetics, 2002, 23(4), 809-813. PMid:12296625.

PETSCH, D.K., PINHA, G.D. and TAKEDA, A.M. Dispersal mode and flooding regime as drivers of benthic metacommunity structure in a Neotropical floodplain. Hydrobiologia, 2017, 788(1), 131-141. http://dx.doi.org/10.1007/s10750-016-2993-2.

PETCHEY, O.L. and GASTON, K.J. Functional diversity (FD), species richness and community composition. Ecology Letters, 2002, 5(3), 402-411. http://dx.doi. org/10.1046/j.1461-0248.2002.00339.x.

PINEDA, A., MORESCO, G.A., PAULA, A.C.M., NOGUEIRA, L.M., IATSKIU, P., SOUZA, Y.R., REIS, L.M. and RODRIGUES, L.C. Rivers affect the biovolume and functional traits of phytoplankton in floodplain lakes. Acta Limnologica Brasiliensia, 2017, 29(0), e113. http://dx.doi.org/10.1590/ s2179-975x 7317 . 
R DEVELOPMENT CORE TEAM $R$ : A language and environment for statistical computing. Vienna, Austria: R Foundation for Statistical Computing, 2014 [viewed 18 Dec. 2019]. Available from: http:// www.R-project.org/.

RAGONHA, F.H., PETSCH, D.K., ALVES, G.H.Z., SANTANA, H.S., MICHELAN, T.S. and TAKEDA, A.M. Tributaries as richness source for Oligochaeta assemblage (Annelida) of Neotropical dammed river. Brazilian Journal of Biology = Revista Brasileira de Biologia, 2014, 74(4), 861-869. http://dx.doi. org/10.1590/1519-6984.05613. PMid:25627596.

RICKLEFS, R.E. Community diversity: Relative roles of local and regional processes. Science, 1987, 235(4785), 167-171. http://dx.doi.org/10.1126/ science.235.4785.167. PMid:17778629.

ROBERTO, M.C., SANTANA, N.N. and THOMAZ, S.M. Limnology in the Upper Paraná river floodplain: large-scale spatial and temporal patterns, and the influence of reservoirs. Brazilian Journal of Biology = Revista Brasileira de Biologia, 2009, 69(2, Suppl.), 717-725. http://dx.doi.org/10.1590/S151969842009000300025 . PMid:19738977.

RODRIGUES, L. and BICUDO, D.C. Similarity among periphyton algal communities in a lentic-lotic gradient of the upper Paraná river floodplain, Brazil. Brazilian Journal of Botany, 2001, 24(3), 235-248. http:// dx.doi.org/10.1590/S0100-84042001000300001.

RODRIGUES, L.C., TRAIN, S., BOVOSCOMPARIN, V.M., JATI, S., BORSALLI, C.C.J. and MARENGONI, E. Interannual variability of phytoplankton in the main rivers of the Upper Paraná River floodplain, Brazil: influence of upstream reservoirs. Brazilian Journal of Biology = Revista Brasileira de Biologia, 2009, 69(2, Suppl), 501-516. http://dx.doi.org/10.1590/S151969842009000300006. PMid:19738958.

RODRIGUES, A.C., SANTANA, H.S., BAUMGARTNER, M.T. and GOMES, L.C. Coexistence between native and nonnative species: the invasion process and adjustments in distribution through time for congeneric piranhas in a Neotropical floodplain. Hydrobiologia, 2018, 817(1), 279-291. http://dx.doi.org/10.1007/s10750-018-3541-z.

ROSIN, G.C., OLIVEIRA-MANGAROTTI, D.P., TAKEDA, A.M. and BUTAKKA, C.M.M. Consequences of a dam construction upstream from the Upper Paraná River floodplain (Brazil): temporal analysis of the Chironomidae community over an eight-year period. Brazilian Journal of Biology = Revista Brasileira de Biologia, 2009, 69(2, Suppl.), 591-608. http://dx.doi.org/10.1590/S151969842009000300014 . PMid:19738966.

RUARO, R., TRAMONTE, R.P., BUOSI, P.R.B., MANETTA, G.I. and BENEDITO, E. Trends in Studies of Nonnative Populations: Invasions in the Upper Paraná River Floodplain. Wetlands, 2019, 39, 1-12.
RUWER, D.T. and RODRIGUES, L. Subfossil and periphytic diatoms from the upper Paraná river, Brazil; last -1000 years of a transition period. Hoehnea, 2017, 45(3), 421-449.

RUWER, D.T., BERNARDES, M.C. and RODRIGUES, L. Diatom responses to environmental changes in the Upper Paraná River floodplain (Brazil) during the last -1000 years. Journal of Paleolimnology, 2018, 60(4), 543-551. http://dx.doi.org/10.1007/s10933018-0039-7.

SCHNECK, F., SCHWARZBOLD, A. and MELO, A.S. Substrate roughness affects stream benthic algal diversity assemblage composition, and nestedness. The North American Benthological Society, 2011, 30(4), 1042-1056. http://dx.doi.org/10.1899/11044.1.

SCHÖN, I., HIGUTI, J., PATEL, T. and MARTENS, $\mathrm{K}$. Aquatic long-distance dispersal and vicariance shape the evolution of an ostracod species complex (Crustacea) in four major Brazilian floodplains. Molecular Phylogenetics and Evolution, 2018, 121, 8697. http://dx.doi.org/10.1016/j.ympev.2017.12.019. PMid:29258880.

SOARES, C.E.A., VELHO, L.F.M., LANSAC-TÔHA, F.A., BONECKER, C.C., LANDEIRO, V.L. and BINI, L.M. The likely effects of river impoundment on beta-diversity of a floodplain zooplankton metacommunity. Natureza \& Conservação, 2015, 13(1), 74-79. http://dx.doi.org/10.1016/j. ncon.2015.04.002.

SOCOLAR, J.B., GILROY, J.J., KUNIN, W.E. and EDWARDS, D.P. How should beta-diversity inform biodiversity conservation? Trends in Ecology \& Evolution, 2016, 31(1), 67-80. http://dx.doi. org/10.1016/j.tree.2015.11.005. PMid:26701706.

SOININEN, J., MCDONALD, R. and HILLEBRAND, $\mathrm{H}$. The distance decay of similarity in ecological communities. Ecography, 2007, 30(1), 3-12. http:// dx.doi.org/10.1111/j.0906-7590.2007.04817.x.

SOUZA, W.Z.T., THOMAZ, S.M. and MURPHY, J.K. Response of native Egeria najas Planch. and invasive Hydrilla verticillata (L.f.) Royle to altered hydroecological regime in a subtropical river. Aquatic Botany, 2010, 92(1), 40-48. http://dx.doi. org/10.1016/j.aquabot.2009.10.002.

SOUZA-FILHO, E.E. Evaluation of the Upper Paraná River discharged controlled by reservoir. Brazilian Journal of Biology $=$ Revista Brasileira de Biologia, 2009, 69(2, Suppl), 707-716. http:// dx.doi.org/10.1590/S1519-69842009000300024. PMid: 19738976.

SOUZA-FILHO, E.E. and STEVAUX, J.C. Geologia e geomorfologia do complexo rio Baía, Curutuba, Ivinhema, In: A.E.A.M. VAZZOLER, A.A. AGOSTINHO and N.S. HAHN, eds. A planície de inundaçāo do alto rio Paraná: aspectos físicos, biológicos e socioeconômicos. Maringá: EDUEM, 1997, pp. 3-46. 
STEVAUX, J.C., SOUZA-FILHO, E.E. and JABUR, I.C. A história quaternária do rio Paraná em seu alto curso. In: A.E.A.M. VAZZOLER, A.A. AGOSTINHO and N.S. HAHN, eds. A Planicie de inundação do Alto Rio Paraná: aspectos físicos, biológicos e socio-econômicos. Maringá: EDUEM. 1997, pp. 47-72.

STEVAUX, J.C., MARTINS, D.P. and MEURER, $M$. Changes in a large regulated tropical river: The Paraná River downstream from the Porto Primavera Dam, Brazil. Geomorphology, 2009, 113(3), 230-238. http://dx.doi.org/10.1016/j.geomorph.2009.03.015.

STRAŠKRABA, M., TUNDISE, J.G. and DUNCAN, A. Comparative Reservoir Limnology and Water Quality Management. Dordrecht: Kluwer Academic Publishers, 1993, 293 p. http://dx.doi. org/10.1007/978-94-017-1096-1.

STREHL, L. and SANTOS, C.A. Qualitity indication of scientific activity (Indicadores de qualidade da atividade científica). Ciência Hoje, 2002, 31(186), 34-39.

SUZUKI, H.I., AGOSTINHO, A.A., BAILlY, D., GIMENES, M.F., JÚLIO-JÚNIOR, H.F. and GOMES, L.C. Inter-annual variations in the abundance of young-of-the-year of migratory fishes in the Upper Paraná River floodplain: relations with hydrographic attributes. Brazilian Journal of Biology = Revista Brasileira de Biologia, 2009, 69(2, Suppl), 649-660. http://dx.doi.org/10.1590/S151969842009000300019. PMid:19738971.

TAKEDA, A.M. Oligochaeta community of alluvial upper Paraná River, Brazil: Spatial and temporal distribution (1987-1988). Hydrobiologia, 1999, 412, 35-42. http://dx.doi.org/10.1023/A:1003844131148.

THOMAZ, S.M., CHAMBERS, P.A., PIERINI, S.A. and PEREIRA, G. Effects of phosphorus and nitrogen amendments on the growth of Egeria najas. Aquatic Botany, 2007, 86(2), 191-196. http://dx.doi. org/10.1016/j.aquabot.2006.10.004.

THOMAZ, S.M., BINI, L.M., PAGIORO, T.A., MURPHY, K.J., SANTOS, A.M. and SOUZA, D.C. Aquatic macrophytes: diversity, biomass and decompostition. In: S.M. THOMAZ, A.A. AGOSTINHO and N.S. HAHN, eds. The upper Paraná River and its floodplain: physical aspects, ecology and conservation. The Netherlands: Backhuys Publishers, 2004, pp. 331-352.

TILMAN, D. Functional diversity. In: S.A. LEVIN, ed. Encyclopedia of Biodiversity. New York: Academic Press, 2001, pp. 109-120. vol. 3

TRAIN, S. Flutuaçôes temporais da comunidade fitoplanctônica do subsistema rio Baia - Lagoa do Guaraná, Planície de inundação do alto rio Paraná (Bataiporã, MS) [Tese de doutorado]. São Carlos: EESC/USP, 1998.
TRAIN, S. and RODRIGUES, L.C. Distribuição espaço-temporal da comunidade fitoplanctônica. In: A.E.A.M. VAZZOLER, A.A. AGOSTINHO and N.S. HAHN, eds. A planície de inundação do alto rio Paraná: aspectos físicos, biológicos e socioeconômicos. Maringá: EDUEM, 1997, pp.103-13.

TRUITI, M.C.T., FERREIRA, I.C., ZAMUNER, M.L., NAKAMURA, C.V., SARRAGIOTTO, M.H. and SOUZA, M.C. Antiprotozoal and molluscicidal activities of five Brazilian plants. Brazilian Journal of Medical and Biological Research, 2005, 38(12), 1873-1878. http://dx.doi.org/10.1590/S0100879X2005001200016. PMid:16302102.

VAN, T.K., WHEELER, G.S. and CENTER, T.D. Competition between Hydrilla Verticillata and Vallisneria americana as influenced by soil fertility. Aquatic Botany, 1999, 62(4), 225-233. http://dx.doi. org/10.1016/S0304-3770(98)00100-4.

VELHO, L.F.M., LANSAC-TÔHA, F.A. and BINI, L.M. Spatial and temporal variation in densities of testate amoebae in the plankton of the upper Paraná river. Hydrobiologia, 1999, 411(1), 103-113. http:// dx.doi.org/10.1023/A:1003889331767.

VITULE, J.R.S., FREIRE, C.A. and SIMBERLOFF, D. Introduction of non-native freshwater fish can certainly be bad. Fish and Fisheries, 2009, 10(1), 98-108. http://dx.doi.org/10.1111/j.14672979.2008.00312.x.

WANG, J., YU, D., XIONG, W. and HAN, Y. Above- and belowground competition between two submersed macrophytes. Hydrobiologia, 2008, 607(1), 113-122. http://dx.doi.org/10.1007/s10750008-9371-7.

WARD, J.V. and STANFORD, J.A. The serial discontinuity concept of lotic ecosystems. In: T.D. FONTAINE and S.M. BARTELL, eds. Dynamics of lotic ecosystems. Ann Arbor Science, 1983, pp.29-42.

WICKHAM, H. ggplot2: Elegant graphics for data analysis. New York: Springer-Verlag, 2009.

WITTMANN, F., HOUSEHOLDER, J.E., OLIVEIRA WITTMANN, A., LOPES, A., JUNK, W.J. and PIEDADE, M.T.F. Implementation of the Ramsar convention on south American wetlands: an update. Research and Reports in Biodiversity Studies, 2018, 4, 47-58.

ZANCO, B.F., PINEDA, A., BORTOLINI, J.C., JATI, S. and RODRIGUES, L.C. Phytoplankton functional groups indicators of environmental conditions in floodplain rivers and lakes of the Paraná Basin. Acta Limnologica Brasiliensia, 2017, 29(0), e119. http://dx.doi.org/10.1590/s2179-975x8117.

Received: 18 December 2019 Accepted: 04 July 2020

Associate Editor: Luiz Ubiratan Hepp 